\title{
License to Critique: A Communication Perspective on Sustainability Standards
}

\author{
Lars Thøger Christensen \\ Mette Morsing \\ Ole Thyssen \\ Copenhagen Business School
}

\begin{abstract}
Sustainability standards are important governance tools for addressing social and environmental challenges. Yet, such tools are often criticized for being either too open-ended or too restrictive, thereby failing to contribute significantly to the development of sustainable practices. Both dimensions of the critique, however, miss the point. While all standards in principle combine elements of openness and closure, both of which are necessary to keep the sustainability agenda relevant and adaptive, sustainability standards often operate in contexts that favor closure. In this article, we draw on a research tradition that views communication as constitutive of organization to emphasize the significance of communicative mechanisms that stimulate organizational openness in the application of standards. With the notion of "license to critique," we present a managerial philosophy designed to involve managers and employees, mobilize and develop their knowledge about sustainability and bring it forward for the benefit of both the organization and the environment.
\end{abstract}

KEY WORDS: sustainability standards, communication as constitutive of organization, discursive closure, discursive opening, license to critique

\section{INTRODUCTION}

$\mathrm{M}$ ANAGERS ARE INCREASINGLY EXPECTED TO adopt sustainability standards as shared, authoritative and recognized reference points at both local and global levels of operation (Rasche, 2010). In a context of global "governance voids" (Gilbert, Rasche, \& Waddock, 2011), sustainability standards such as UN Global Compact and SA8000 are assumed to stimulate, guide, and help organizations account for socially and environmentally desirable behavior and to support different constituencies in governing organizations at a distance (Miller \& Rose, 1990). The popularity of such ubiquitous standards (Timmermans \& Epstein, 2010) lies in their appeal to serve many interests across sectors and industries (Steelman \& Rivera, 2006) and is witnessed by their growing market shares, a development that has taken place especially over the past three decades (Reinecke, Manning, \& Hagen, 2012).

Along with increased popularity, however, dissatisfaction is emerging. Sustainability standards are criticized for not delivering the expected improvements to business 
and society. Some standards, for example, are criticized for being too open-ended and vague. Such standards are described as "lofty pronouncements" with low impact, especially because they do not require organizations to provide concrete information about their practices (Sethi \& Schepers, 2014: 193). Simultaneously, the quest for more detailed and accurate specification of practices and behaviors, required by other standards, is criticized for being too closed, thus lacking sensitivity to local conditions. In such cases, the critique goes, compliance is reduced to annual exercises of "ticking the boxes," thereby excluding necessary reflection on the standard's limitations and discussions about potentially better practices (Rasche, 2010).

In contrast to these positions, a number of scholars have pointed out that dimensions of openness and closure usually coexist in the implementation and use of a standard. In their study of SA 8000, for example, Rasche \& Esser (2007) illustrated the co-existence of "option-excluding and discourse-opening moments" (124). These moments, according to Rasche and Esser, allow SA 8000 to combine what they referred to as a "straightforward compliance orientation with a communicative and value-based understanding of integrity" (122). In line with this observation, Ansari, Fiss, and Zajac (2010) have, for example, argued that management practices are not adopted as "off-the-shelf" solutions, but are rather diffused into organizational practices. The meaning and content of even the most stringent standards need to be reconstructed by professionals (Edelman, 1992; see also Behnam \& Maclean, 2011; Delmas \& Montes-Santo, 2011; Edelman \& Talesh, 2011) or consultants (Brés \& Gond, 2014) of adopting organizations. These observations and arguments are highly important in order to arrive at a more sophisticated understanding of standards and their potential role in pushing and developing the sustainability agenda.

In this article, however, we take a slightly different perspective. While we fully acknowledge that all standards combine elements of openness and closure, both of which are necessary to keep the sustainability agenda relevant and adaptive to new situations, we point out that sustainability standards often operate in contexts that favor closure. Such inclination towards closure may be driven by social pressure for compliance, the design of the standards themselves and the ways the standards are implemented and used by contemporary organizations. To offset this tendency, which threatens the development of the field, we argue that managers and employees must systematically integrate inquiry and contestation of sustainability standards in organizational practices. Hereby, we suggest a reinvigoration of the social dynamics that originally stimulated the development of sustainability standards. We refer to such dynamics as "license to critique."

More specifically, we draw on a research tradition that regards communication as constitutive for organization (Taylor \& Van Every, 2000) to argue that ongoing talk about sustainability, including critique and contestation of standards, are vital dimensions in processes of adopting, fine-tuning, and developing sustainability standards to fit changing social and environmental problems. As such, we contribute to the emergent literature on sustainability standards that focus on how standards are influencing and influenced by organizational members (e.g. Terlaak, 2007; Wickert \& de Bakker, 2015). 
The remaining article is organized along the following two major parts. The first part discusses the propensity towards closure and the various drivers that reduce flexibility in the organizational use of sustainability standards: closure by the past, closure by design, and closure by routinization. The second part presents the notion of "license to critique" and unpacks in some detail under three headlines (1) the organizing practices: communicative constitution of standards, standards as sensitizing devices, and value of critique and contestation; (2) the communicative principles: confronting alternatives, authorizing participation, and talking to learn; and (3) the mechanisms of critique: spaces for dissent, tolerance for aspirations, and standards as change agents.

\section{SUSTAINABILITY STANDARDS AND THE PROCLIVITY TOWARDS CLOSURE}

Sustainability standards may be understood as "voluntary predefined norms and procedures for organizational behavior with regard to social and/or environmental issues" (Rasche, 2010: 280; see also Gilbert \& Rasche, 2007). The ambition behind such standards is to "systematically assess, measure and communicate" the social and environmental behavior of contemporary organizations (Gilbert, Rasche, \& Waddock, 2011: 23). Unlike codes of conduct, which are formulated by organizations themselves, sustainability standards are usually developed, designed, and assessed by international organizations, governments, or multi-stakeholder initiatives outside the adopting organization with the intent of prescribing and shaping the dos and don'ts in the sustainability arena (Brunsson, Rasche, \& Seidl, 2013).

Most such standards arise in areas of "governance voids" (Rasche, 2012), that is, when organizations operate in transnational spheres where regulation is absent or non-enforceable and where "norms are likely to fail" (Terlaak, 2007: 972). Part of their popularity is attributed to the fact that they substitute public regulation across nations with "private rules" (Schuler \& Christmann, 2011) and offer the possibility of differentiation and upgrading that can increase competitiveness for producers and traders (Bitzer, Francken, \& Glasbergen, 2008). Being non-binding in a legal sense, however, such standards are often described as "soft law": they are voluntarily adopted, carry no legal mandate, and no legal sanctionary mechanisms (Rasche, 2009). Sustainability standards, in other words, are often regarded as too open-ended. Combined with the fact that different definitions create confusion among practitioners and scholars (Carroll, 1979; Dahlsrud, 2006), this feature has led to characterizations of sustainability as an "opaque field" (Wijen, 2014) and an "essentially contested concept" (Okoye, 2009).

In contrast to such characterizations, however, we suggest that the ambiguous and open-ended nature of sustainability may serve the phenomenon itself: sustainability and its various stakeholders. Since problems, challenges, and issues change across time and context, sustainability is necessarily a "moving target" (Guthey \& Morsing, 2014) "in a state of continuing emergence" (Lockett, Moon, \& Visser, 2006). Precisely because of its ambiguous nature, it allows for sense-making and participation from many different stakeholders with diverse interests and expectations 
(McWilliams, Siegel, \& Wright, 2006). Despite these potential advantages of open standards, we note at present a trend towards closure.

In the context of sustainability standards, we understand "closure" as the termination of reflection and debate about what sustainability means or could mean for organizations and society. Such closure may, for example, lead to blocking or short-circuiting of ethical considerations (Kärreman \& Alvesson, 2003) or the promotion of discursive practices that suspend dissent, difference, and discussion (Deetz, 1992). Under conditions of closure, curiosity and argument about sustainability are replaced by attempts to manage the standards, to transform their ideals into technical measures, and to document their impacts on organizational practices. Hereby, investigations of urgent complex matters of social and environmental concerns are avoided by referring to compliance with a standard. And while such change in focus is understandable for many reasons, it simultaneously has a number of disadvantages for the subject matter itself: sustainability. As we shall argue in the following, closure occurs at different levels and may have many different sources, including social pressure for alignment between past commitments and current practices, the design of the standards themselves, and the ways the standards are implemented and used by contemporary organizations.

\section{Closure by the Past}

An ongoing concern in contemporary society is how to make adopting organizations live up to sustainability ideals (Rasche, 2010). The standard literature, thus, as well as most organizational practice, is guided by the assumption that standards perform most effectively when there is alignment, or tight couplings, between policies, practices, and output (e.g. Christmann \& Taylor, 2006; Fransen \& Kolk, 2007). Among standard setters, certification agents, and managers, accordingly, there is much focus on how to avoid inconsistencies between sustainability prescriptions of the standards and the actual practices of standard adopters. And while NGOs, corporate critics, and researchers are looking for "gaps" between the two (Aravind \& Christmann, 2011; Boiral, 2003), much research examines the extent to which sustainability claims are comprehensively and clearly reflected in the core activities of adopting organizations (e.g. Kwon, Seo, \& Seo, 2002; Morhardt, Baird, \& Freeman, 2002). One inherent challenge is that the company's sustainability efforts per se become oriented less towards the future than towards the past in which the standards were formulated. Issues and concerns of the past come to define what living up to sustainability standards implies in the present.

Zeitz and colleagues, for example, have termed the notion of "entrenchment" to give attention to substantial rather than superficial (or "ceremonial") integration of sustainability policies, emphasizing how endurance and persistence of sustainability promises made in the past need to permeate the adopting organization today (Zeitz, Mittal, \& McAuley, 1999). Such concern about decoupling between talk and walk, or between ethical standards and organizational structures, is not new (e.g. Weaver, Trevino, \& Cochran, 1999). Yet recent research has noted how the quest for alignment between talk and action in today's society is particularly prevalent in the areas 
of responsibility and sustainability, where tight couplings between programs and action are regarded as a sign of ethical behavior (Christensen, Morsing, \& Thyssen, 2013) and where inconsistencies between past promises and current behavior are described as "greenwashing" (Delmas \& Burbano, 2011).

Together, these tendencies promote closure in sustainability programs and practices. The narrow focus on entrenchment and consistency-and especially the "gap-hunting" that comes along with it - make organizational actors keen to practice what they preach. In this process, however, organizations tend to orient themselves towards the past and thereby miss the chance of discovering something new (Weick, 1995). Prior research has demonstrated how adoption is mostly a process of preparing documentation, which is per se oriented towards the past (González-Benito \& González-Benito, 2005). Such alignment regimes, in which goals articulated yesterday discipline and constrain current behavior, leave little room for doubt, experimentation, and future commitments.

\section{Closure by Design}

Some sustainability standards, by their very design, tend to invite closure. Through their focus on compliance with a set of relatively detailed expectations for proper organizational practices and behaviors, certification and reporting standards, in particular, represent such proclivity towards closure. Among the most common certification standards are Social Accountability 8000, Fairtrade, ISO 14001 Environmental Management Standards, and Forest Stewardship Council. Such standards are intended to reduce the negative impacts of corporate activities on the environment and the workers by delineating quite specific targets for desired behavior. While Fairtrade, for example, specifies fair labor conditions, the Forest Stewardship Council defines performance criteria for industries specifying, for example, the percentages of types of wood used in products. Organizations may be awarded with a certificate as a "seal of approval" when they have passed an evaluation by an independent thirdparty auditor that verifies how they comply with the certifiable standard. Reporting standards similarly propose rather detailed frameworks for organizational information disclosure on sustainability activities and achievements. Some of the most well-known examples are the Global Reporting Initiative (GRI) and the rules set by the Carbon Disclosure Project (CDP). These are predefined disclosure and reporting systems designed to help organizations describe existing activities in systematic ways ("this is what we do and this is what have we achieved").

One important aspect of the organizational exercise to become certified or to produce a sustainability report is the production of manuals and rules that chart how to handle pre-defined situations. Even if certification and reporting standards provide some leeway and allow for interpretation across situations and organizations, the adoption of these standards requires conformity to rather strict procedures. The call for interested parties to compare and contrast the results across organizations and over time furthers an attention to specificity and detail. While it has been duly noted that much conformity may be ceremonial, rather than substantial (Bromley \& Powell, 2012), it is worth noting that the legitimacy of certification standards and 
producing sustainability reports hinges on stakeholders trust in the information provided. At the same time, high rankings within the frameworks of such standards is likely to have a positive effect on corporate image, something which causes many organizations to use certifications and sustainability reports to convey their social and environmental engagement to external stakeholders such as NGOs and customers (King, Lenox, \& Terlaak, 2005). Such potential image effects may further incentivize organizations to follow reporting standards to the letter.

\section{Closure by Routinization}

The organizational implementation and use of sustainability standards may also produce closure, even for standards that are more open-ended. Principle-based sustainability standards such as United Nation's Global Compact (UNGC) or Principles for Responsible Investment (PRI) are designed to guide organizational behavior rather than manage or measure it. As such, they are formulated as relatively openended principles with the intention of inspiring rather than steering practice. Still, enduring practices may gradually turn such open-ended standards into manageable routines that are tantamount to closure.

Research on change and learning, for example, has demonstrated how behavior, which is repeated over and over, is likely to develop into behavioral paths that are difficult to change (Becker, Lazaric, Nelson, \& Winter, 2005; see also Argyris \& Schon, 1996). The inclination to develop "defensive routines" is a skilled human strategy to protect individuals from examination, discussion, and possible uncomfortable change (Argyris, 1976). UNGC, for instance, is designed to motivate and guide new sustainability efforts. At the same time, however, corporate signatories are requested to produce a bi-annual Report on Progress to retain their membership. While UNGC does not provide specific reporting guidelines, in practice companies tend to rely on routines or rules of thumb learned from experience or adapted by others, for example, based on commonly recognized reporting practices (Cyert \& March, 1963). A study of UNGC's implementation survey, for example, shows that $67 \%$ of all signatories have been inspired by anti-corruption principles in developing their own codes of conduct (Woo, 2010). Once formulated to fit organizational practices, standards become rules that resist not only reformulation but, more importantly, flexibility (March \& Simon, 1958). Although all sustainability standards allow for some "interpretative flexibility" that may help organizations adapt them to specific circumstances (Ansari et al., 2010; Rasche, 2009), the strong inclination to develop rules that are easily implementable and verifiable tends to suppress such potential. Terlaak (2007) has labeled this problem the "double-edged sword" of standards, and Wijen has discussed how the privileging of specificity "to ensure compliance may compromise the achievement of the intended goal” (2014: 313).

\section{Problematizing the Bias toward Closure}

Given a context of public suspicion and distrust, shaped by financial crises as well as numerous cases of corporate fraud, a call for stricter regulation and more detailed standards seems reasonable. Yet, such proclivity towards closure is problematic for 
several reasons. First, closure naturalizes sustainability standards as the "normal thing to do" that cannot be legitimately challenged or questioned (Deetz, 1992). Second, closure transfers responsibility from the organization to the standard itself in a way that allows the company to demonstrate responsiveness without responsibility: "It is not our fault. We are complying with the standard." Third, closure supports existing bureaucratic structures, which means that organizations will have a tendency to focus on fulfilling goals of earlier relevance rather than facing up to new and future situations. As Haack and colleagues point out, the ideal of closure between programs, practices, and outcomes has been criticized for several reasons, primarily because persistence and "real impact" only can be decided in retrospect (Haack, Schoeneborn, \& Wickert, 2012) and because decoupling is overlooked as a possibly transitory phenomenon (Haack et al., 2012; see also Haack \& Schoeneborn, 2014). Still, sustainability standards direct organizations' way of observing and making decisions and hence provide closure in directing orientation towards the past rather than the future. Such a mechanism has been described as "the dead hand of the past" (Thyssen, 2009: 119).

Looking at the communicative practices involved, we notice along with Deetz (1992) that closure turns standards into privileged discourses that constrain participation and sincere involvement. Privileged discourses, according to Deetz, tend to benefit certain organizational positions and understandings and thereby imply a premature truncation or containment of a discussion. Deetz refers to such processes as discursive closure: "When discussion is thwarted, a particular view of reality is maintained at the expense of equally plausible ones, usually to someone's advantage" (Deetz, 1992: 188). Examples of discursive closure in the context of sustainability standards includes the propensity to downplay or squeeze out controversial sustainability themes such as equality or discrimination when consultants assist managers in responding to sustainability regulations and standards (Brés \& Gond, 2014). Research has also pointed out how standard developers close in on certain issues and themes and thereby influence behavioral patterns of an entire industry as they carry out strategies to develop their own legitimacy (Déjean, Gond, \& Leca, 2004). Such closure may also arise when organizations decide to ban child labor among its suppliers in order to adhere to the UNGC principle 5: "Businesses should support and respect the effective abolition of child labor." While the intention behind such a ban may be noble, it might impel companies to focus narrowly on distancing themselves from such practice-changing suppliers or geographical locationsthereby producing unintended side effects such as impoverishment of families and the children whose chance of attending school is therefore further reduced.

Closure may satisfy a desire to make standards more effective, helping standard developers, standard accountants, and managers setting and justifying specific targets and deciding on precise means of measurement and thereby facilitating comparisons and organizational compliance. The significance of such concerns should not be underestimated. In the broader perspective, however, other considerations such as sensitivity to specific conditions and applications and the need to incorporate experiences from local users speaks against a bias towards closure. Arguing from this perspective, Deetz (1992) invites us to step back for a moment and pay attention 
to the possible communicative pathology associated with such one-sided understandings of standards and the values they represent. Not only is discursive closure a threat to participation and democracy (see also, Timmermanns \& Epstein, 2010), it simultaneously prevents organizations and society from learning and improving their practices.

Power (1997) has similar concerns in mind in his cogent critique of the auditing institution. In line with Deetz, Power argues that a bias towards fixed standards and formalized evaluation procedures precludes participation and limits insight. While auditing is usually regarded as a benchmark for securing organizational legitimacy and accountability, it presupposes a more or less blind trust in the experts that develop the standards and those who perform the assessments and reviews. As such, it tends to squeeze out open debate and deliberation. Auditing, thus, becomes a new form of image management that discourages public inquisitiveness. In this respect, the administration of standards (of which the audit plays a central role) may become "a substitute for democracy rather than its aid" and "a dead end in the chain of accountability" (Power, 1997: 127; see also, Strathern, 2000).

Importantly, we are not suggesting that those who set the standards or those who follow them are interested in systematically closing off potentially fruitful discussions. Discursive closure is not necessarily organized as a planned strategy or "intensely governed" (Rose, 1989: 1). Still, it may gradually emerge and become normal practice through slow, quiet, and repetitive micro-practices of reducing uncertainty (Weick, 1979), for example, through the development of still more pre-defined, quantifiable, and comparable routines.

In the next section we consider from a communicative perspective how the inclination towards closure and the associated problems may be counterbalanced by organizational practices that stimulate questioning and contestation. We describe such practices as a "license to critique" (Knudsen, 2004).

\section{LICENSE TO CRITIQUE}

License to critique means that critique is recognized as an important and necessary dimension of organizational development and that ongoing assessments of organizational practices therefore are welcomed, indeed encouraged, from all corners of the organization. The critique involved may take the shape of, for example, criticisms, appraisals, examinations, opinions, argumentations, or the suggestion of alternatives, provided the critique is delivered in the interest of organizational improvement. Such input, it is believed, is rich and essential to organizational development (cf. Christensen, Morsing, \& Cheney, 2008). License to critique, thus, is a managerial philosophy designed to involve managers and employees, draw on their insights, and stimulate their critical thinking while avoiding a premature closing down of discussions along with a potential to improve organizational practices. Based on the assumption that knowledge is distributed among individuals at different functional and hierarchical levels rather than concentrated exclusively in the hands of management (cf. Fagin, Halpern, Moses, \& Vardi, 1995), a license to critique approach is essentially an invitation to organizational members to mobilize and develop their 
knowledge and to bring it forward to benefit the organization and, eventually, the wider society.

In the particular context of sustainability standards, the license to critique is focused primarily on improvements that benefit the environment and the workers. While other work has focused on how to reduce the burden of the adopting organization to implement the plethora of norms, guidelines, and regulatory advice (Chatterji \& Levine, 2006), we propose a license-to-critique approach that describes how to expand and improve the use of all these standards. The license-to-critique approach calls for organizations to deliberately sensitize themselves to local insights and experiences about sustainability issues while actively seeking to transform such insights and experiences into improved sustainability practices. While unpacking and implementing a specific sustainability standard, the organization may involve its employees in brainstorming about the standard's limitations in the context of its specific product line. A dairy producer, for example, may urge its employees to think beyond the standard on issues such as waste reduction, something that may lead to the use of new types of packaging, increased recycling, and more efficient production. The license to critique may focus on the sustainability standard itself, including its implied values and areas of measurement, or the organization's use of the standard in its daily practices. What is important is that the discussion about sustainability is kept alive. In this perspective, communication is not regarded as a passive tool that merely expresses reality, but an organizing practice that contributes to its ongoing creation (Ashcraft, Kuhn, \& Cooren, 2009; Brummans, Cooren, Robichaud, \& Taylor, 2014).

\section{Organizing Practices}

The Communicative Constitution of Standards

According to a growing number of organizational scholars, organizations are not given in advance of talk or seen to exist outside communicative practices, but are "precarious accomplishments" realized in communication (Cooren, Kuhn, Cornelissen, \& Clarke, 2011; see also, Boje, Oswick, \& Ford, 2004; Cooren, 1999; Fairhurst \& Putnam, 2004; Grant, Keenoy, \& Oswick, 1998; Luhmann, 1995; Seidl, 2005; Taylor \& Van Every, 2000). Communication, in this view, is not a separate organizational sphere or domain easily discernible from other organizational practices (Luhmann, 1995), but constitutive activities through which organizations emerge, that is, are founded, shaped, reproduced and eventually transformed (Ashcraft, et al., 2009; Schoeneborn, 2011). With its focus on emergence (Taylor \& Van Every, 2000), this perspective is well suited to investigate the conditions under which communication may produce new types of organizational practices.

To appreciate the relevance of this view in the context of sustainability standards, it is useful to consider subscription to a standard as a particular kind of communication or speech act. Speech acts are utterances with performative functions, in other words utterances that $d o$ something (Austin, 1962; Searle, 1969). And while speech act theory has emphasized that all speech is action, a number of distinctions are important in order to recognize what standards might do (see also, Cooren, 2004). 
Initially, we emphasize that subscriptions to standards do not merely describe or report on some completed action or an already existing organizational reality. They are, in other words, not "constatives" that can be judged as true or false (Austin, 1962). Rather, subscriptions to standards are declarations or "commissives" that "furnish a script" (Taylor \& Van Every, 2000: 4) for organizational reality thereby committing subscribers to behave in a specific manner (Taylor \& Cooren, 1997). Whereas declarations are speech acts that instantly change reality in accordance with its implied proposition (e.g. announcing that the organization is now a member of a specific sustainability network), commissives, such as promises or oaths, are more future-oriented, committing its speaker to begin to set certain activities in motion.

While such speech acts may not always perform precisely as anticipated or hoped for (Austin, 1979), certain expectations for follow-up action are implied by the words, thereby shaping organizational reality in various ways (see, e.g., Christensen et al., 2013; Haack et al., 2012; Livesey, 2002). Communication about standards, thus, is constitutive of organizational reality and a potential source of organizational emergence. For example, when managers and other organizational members critique a particular standard or talk about how to reduce consumption of electricity in accordance with its suggested measurements, they do not merely apply a fixed reality, but start communicating a "new" organization into existence (Taylor \& Van Every, 2000), an organization in which sustainability awareness is now a significant differentiator.

\section{Standards as Sensitizing Devices}

The adoption of a standard can be understood as a decision to raise organizational sensitivity to a specific domain, for example, the domain of sustainability. By doing that, the organization allows itself to be "irritated," as Luhmann (1995: 172) puts it, by certain types of external stimuli (here: stimuli related to sustainability) while ignoring others. Although such distinctions take place all the time-and are necessary to avoid being overwhelmed by a surplus of information-it simultaneously means that organizations must remain insensitive to most of what takes place in their surroundings. In the process of selecting what is relevant, therefore, the organization is not passively transforming input into output, but is reducing complexity and producing information. The ways organizations sensitize themselves to the domain defined by a standard are, in other words, highly important, because they significantly shape the organization and, potentially, the standard itself.

Organizations can sensitize themselves to the domain of a standard in different ways, depending on the type of standard and the organizational practices applied in its implementation. As we have argued above, certification and reporting standards hold quite different potential for flexibility than do principle-based reporting standards. Yet, the nature of the standard provides only a partial explanation for why some standards are more prone to develop and undergo change, whereas others tend to become mechanical exercises of "ticking the box." While standards may be more or less open to contestation and modification, the realization of such potential depends on the communicative practices involved in their application and daily use. 


\section{The Value of Critique and Contestation}

A constitutive notion of communication suggests that standards are more than authoritative models or reference points that shape organizational practices by funneling them in particular (desirable) directions. While standards often originate outside organizational boundaries, they are not passively received, unpacked, and implemented by corporate actors. Rather, they are enacted, tested, and, eventually, contested through communicative practices. Since communication is not a peripheral phenomenon, that is, something an organization does once in a while in between other important activities, but the primary process through which organizations constitute themselves (e.g., Luhmann, 1995), communication plays a central role in the development of standards as well as in the organizations that subscribe to them. By shaping the conversations through which organizations discover who they are and what they might become, standards have "organizing properties" (Cooren, 1999) with the potential to shape organizations and their environments (cf. Weick, 1979; 1995). Their ongoing development, however, presupposes a willingness as well as an ability to challenge, expand, and improve norms, rules, models, and principles through constant critique and contestation.

Prior research on standards has recognized that standard adoption usually involves processes of negotiation and compromise (Brés \& Gond, 2014; Edelman, 1992). Yet, as these studies indicate, such processes primarily serve to create meaning in the interest of new business opportunities, while ignoring promotion of the sustainability agenda itself. Moreover, this research suggests that basic assumptions about improvement of sustainability and sustainability standards are often not debated, but rather bypassed in order to serve corporate interests.

Yet, contestation of such assumptions and their implied practices is necessary to cultivate a variety of perspectives, ensure commitment among involved parties and stimulate creative solutions (Deetz, 2007; Ferraro, Etzion, \& Gehman, 2015). Boden (1994), for example, has argued that communication is not just an arena for interpretation, but also for action. Based on conversational analyses, she shows how queries in "turn-taking" and "turn-making" processes create opportunities for posing questions, negotiating agreements, expounding opinions, and resolving as well as creating conflicts. Such processes, she argues, are part of organizational strength. Other communication scholars have similarly demonstrated how queries are important resources because "it is in these spaces of difference that alternative ways of thinking (rethinking) and acting emerge" (Livesey et al., 2009: 426). Obviously, this perspective implies a tolerance for difference, including acceptance of different interpretations of the sustainability ideal.

When it comes to complex issues and wicked problems such as social responsibility or sustainability, this logic is acutely relevant. As the last few decades have demonstrated, the meaning of sustainability is not given once and for all (Lockett et al., 2006; Guthey \& Morsing, 2014). Sustainability is a complex and constantly moving target and recognition of its potentials and intricacies depends on its actual use in different situations, organizations, and industries. A subscription to a sustainability standard, for example, makes it possible for an organization to test its 
identity as a sustainability-advancing social actor, and to conjure up future-oriented self-images that are binding in the sense that they provoke questioning, inquiry, and reflection and eventually inspire and obligate the organization to strengthen the links between policy and practice and between means and ends. Sustainability standards, thus, have potential to become fertile arenas for discursive openings, provided a variety of perspectives are cultivated and established positions continuously challenged (Thackaberry, 2004; Christensen et al., 2013). This, however, requires communicative principles that are able to keep the debate about sustainability standards alive by bringing a variety of interpretations, approaches, and experiments into play. We discuss such principles below.

\section{Communicative Principles}

\section{Confronting Alternatives}

The first principle is awareness of alternatives and contingencies. Even if organizations need to seek "closure" in order to remain efficient and therefore tend to establish procedures that desensitize them to most of what happens in their environments, they can selectively decide to be "irritated" - criticized, corrected, provoked-in specific domains. More specifically, organizations can decide to confront (or "irritate") themselves with alternatives. It is in such confrontations that organizations test themselves and their values. According to Luhmann, the very aim of communication is exactly that: "sensitizing the system to chance, disturbances, and noise" in selected areas (1995: 172). Sustainability is an example of a particular area of attention that calls for an ongoing confrontation of alternatives in order to remain vibrant, that is, constantly evolving and relevant to local circumstances.

The license-to-critique approach facilitates such confrontation by regarding the standard as a "lens" through which managers as well as employees are expected to observe and challenge existing ideals, assumptions and practices. Such approach, for example, may inspire participants to discuss what sustainability could mean or imply in specific contexts, to debate possible alternative ways of working with the standard, and to test out "wild" or counter-intuitive proposals in an organizational environment where the tolerance for discrepancies and dissent is high. Thus, when considering the areas of measurement defined by a standard, adopters should regard these areas as suggestions and encourage employees to air doubt and skepticism, pose questions and come up with additional ideas or alternatives that fit its particular products. The dairy producer mentioned above might, for example, collaborate with organizations that provide food for homeless people.

\section{Authorizing Participation}

The second principle is participation. In contrast to Habermasian-oriented approaches to sustainability standards, the license-to-critique approach implies that participation may be more important to the advancement of the sustainability agenda than consensus and agreement (cf. Deetz, 1992). The license-to-critique approach, however, does not suggest totally open, unstructured, or unqualified participation. 
Unstructured participation holds the risk of endless discussions and unmet expectations, which might stifle organizational action. Participation in itself is also not a panacea to complex issues, including democratic deficit (Luhmann, 1995). The aim of the license to critique approach is to establish a system of participation that is sufficiently organized, concrete, and local to encourage and guide involvement without impeding the discovery of new ideas and solutions. Research in the cut flower industry has shown how participatory social auditing is one way to create meaning participation among certification standards (Hale \& Opondo, 2005).

Within such a system, understandings of sustainability standards do not need to be shared among participants. What needs to be shared are the rules of the "game." In a license-to-critique perspective, those rules of the game are akin to what Christensen, Firat, and Torp (2008) call "common process rules," that is, rules that guide processes rather than content. In contrast, for example, to UNGC's guidelines that recommend specific content areas for corporate sustainability engagement, the license to critique approach implies a set of processual rules (or communication principles) that invites participation with a focus on openness, mutuality, and trust, as well as a tolerance for difference and variety. Together, such rules delineate guidelines for involvement and call on organizational members to act constructively in shaping organisational ideas and practices. Simultaneously, they call on managers to allow for intensive boundary spanning and to draw actively and systematically on the day-to-day experiences, ideas, and enactments of standard users. While ideas about how to reduce waste, for example, may come from all corners of the organization, their initiators do not need to follow formalized chains of command when airing them, but may immediately address whoever they feel are able to push the ideas forward.

In a license-to-critique approach, thus, a standard is not a sacrosanct solution, but an "authorized speech position" (Knudsen, 2004) that structures involvement by qualifying and empowering participants to observe and reflect on organizational practices. While knowledge about the promises and perils of a particular sustainability standard may already exist in a rudimentary form among (some) employees, it can sometimes be difficult for subordinates to express such knowledge in ways that convince management (Cheney, Christensen, Zorn, \& Ganesh, 2011), especially as many CSR departments are stuck in "middle management" positions. The institutionalization of a license-to-critique approach makes it possible for employees to articulate their concerns with force and legitimacy, to contest established wisdom, and to challenge superiors and others whose opinions are supported by their rank and seniority rather than expertise.

\section{Talking to Learn}

The third principle emphasizes that communication facilitates learning. Acknowledging that organizations are communicative phenomena that are "talked into existence" (Taylor \& Van Every, 2000), license to critique allows for exploration of possibilities and alternatives in a more fundamental sense than described by the principles and practices of participating, challenging, and responding. Since sustainability is a complex issue without finite answers and solutions, the role of 
communication in this arena is not simply to convey prepackaged ideals and explain necessary practices. Rather, participants, including managers, need to hear themselves talk about sustainability in order to understand what the ideal means to their particular organizations and to discover the possibilities and limitations of the ideal in specific contexts (Christensen et al., 2013; see also, Weick, 1979). Open discussion and critique not only facilitate a wider and deeper implementation of existing sustainability standards, but stimulate ongoing learning about sustainability policies, practices, and outcomes. The dairy producer, for example, may encourage its employees to talk out loud about their personal experiences with waste reduction, to observe their own waste behavior in the light of the sustainability standard, and to imagine better ways to diminish the use of plastic or cardboard or avoid throwing out dairy products. To keep the sustainability agenda vibrant, relevant, and sensitive to local contingencies, organizations need at the very least to establish and maintain mechanisms that facilitate inquiry and dissent (cf. Burt, 2005; Livesey, Hartman, Stafford, \& Shearer, 2009). Such mechanisms acknowledge that talk about sustainability is more than a superficial epiphenomenon that accompanies other sustainability practices, but a type of action in and of itself (e.g. Austin, 1962; Searle, 1969), necessary to learn, and to bring additional action.

In sum, a license to critique is a shorthand notion for a culture devoted to (self)reflection and discussion about basic assumptions, shared values, ideals and practices. Such an attitude may be formally organized and involve a systematic and recurrent solicitation and collection of input from relevant stakeholders. Or it may function more informally through various forms of openness and appreciation of feedback. Either way, it implies a tolerance for critique and diversity. More profoundly, it also implies that management is willing to listen and capable of responding to such input without penalizing the sources of the critique. At the same time, it assumes that employees are participating with a constructive spirit, recognizing that not all "wild" ideas can possibly be implemented.

\section{Mechanisms Of Critique}

Given the many drivers toward closure identified earlier, we propose in the remainder of the article three managerial mechanisms designed to embed a license-to-critique approach in the routines of standard adopters and, in this way, keep the debate about sustainability open. The three mechanisms are not conceived to mobilize a new army of auditors, regulators, and assessment schemes, but to stimulate critical reflection on standards and their use in organizational practices. As such, our proposal bears some resemblance with Rasche and Esser's (2006) call for "inclusion of moral questions into daily organizational decisions" (108). Like Rasche and Esser, our concern is to keep managers and employees reflecting on the intricacies related to standard adoption. As will become clear, however, our idea departs from their ambition of ensuring "consistency between organizational values and actions" (112). In contrast to their Habermas-inspired framework, our argument emphasizes the value of conflictual moments as key drivers of progression and development. The three mechanisms are introduced below. 


\section{Spaces for Dissent}

Firstly, adopting organizations must develop spaces for dissent in which penetrating questions about the strengths and weaknesses of particular sustainability standards can be raised without undue concern for the organizational image vis-à-vis external audiences. In such exclusive spaces, managers and employees can candidly raise organizational dilemmas and focus on taboos or other factors hindering the organization's contribution to improved sustainability. Organizational members may ask questions such as: "Why are we focusing most of our efforts on gender equality when we all know that corruption is our biggest problem?" Or: "Do we want to support a certification association when we disagree with the way it evaluates our 'seal of approval'?" Spaces of dissent may take the shape of brainstorming sessions, laboratory experiments, or various debate forums, where managers and employees across organizational functions seek and exchange counterarguments and concerns. Whereas dissent is usually regarded as a counterproductive force that erodes legitimacy, research on social media has demonstrated how the integration of oppositional voices may add legitimacy to organizations, as long as dialogue thrives and respect is present (Castello, Morsing, \& Schultz, 2013). Moreover, our constitutive perspective on communication suggests that spaces of dissent do not merely provide forums in which critique can be conveyed. If we consider talk as performative (Austin, 1962; Searle, 1969) and accept the notion that organizations emerge in communication (Taylor \& Van Every, 2000), we are able to realize that spaces of dissent simultaneously allow participants to reimagine and recreate their organization, including their understanding of its sustainability practices (e.g., Ashcraft et al., 2009).

\section{Tolerance for Aspirations}

Secondly, we believe that questioning needs to be future oriented in spaces of dissent. While managers and employees are often trained in solving existing problems, fixing difficulties, and getting things done, such orientation towards the present and past is likely to stifle creativity and delay important developments. In complex areas such as sustainability, where definitions and practices are constantly evolving, "aspirational talk" (Christensen et al., 2013) may be necessary to explore and inspire new and better practices. The process of articulating ideals and ambitions out loud is an essential sense-making mechanism that needs to be stimulated and protected by management (e.g., Weick, Sutcliffe, \& Obstfeld, 2005). Moreover, such talk has performative potential in as much as members may feel morally entrapped by their own words (cf. Haack et al., 2012). In a modus of critical aspirational inquiry, members could ask questions such as: "Could we account for animal welfare in our UNGC annual Communication on Progress reports in other ways than simply counting the number of animals in the labs? How about a narrative format that allows us to explain our practices in more depth?" Or: "What are our alternatives to current intransparent investment practices in Panama, now that we have committed to the United Nation's Principle of Responsible Investment?" Such type of questioning that stimulates scenario-thinking has a greater chance of producing long-term achievements 
than critique of past behavior. At the same time, since such practice signals a deep engagement in the sustainability agenda, there is a greater chance that managers and other employees will identify with the organization (Du, Bhattacharaya, \& Sen, 2010; see also Kjærgaard \& Morsing, 2010).

\section{Standards as Change Agents}

Thirdly, the sustainability manager needs to regard the standard as an agent of change rather than as a technical tool that merely guides the administration of sustainability toward compliance. In contrast to most extant research that describes the sustainability manager as an internal preacher, seller, disseminator, or controller whose job is to make sure that the standard is adopted and implemented in accordance with specifications (e.g., Maon, Lindgreen, \& Swaen, 2009; Wickert \& de Bakker, 2015), our license-to-critique perspective suggests that the primary function of the sustainability manager is to facilitate involvement and knowledge sharing. This view implies a far more confrontational and oppositional role of the sustainability manager inasmuch as (s)he needs to stimulate inquiry and constructive critique of the organization's own practices. In this capacity, the sustainability manager assumes a strategic position of facilitating debate and soliciting aspirations. To do that, the sustainability manager needs skills of sensing critical voices, looming scandals, and concerned citizens' voices. The license to critique, in other words, profoundly challenges the conventional notion of the sustainability manager as a disseminator of past experience and all "the good stuff" accomplished by the organization.

\section{CONCLUSION}

The original idea of engaging organizations in the sustainability agenda was to improve social and environmental conditions. The role of sustainability standards is to ensure that corporations actually $d o$ engage in ways that make a positive difference. To that purpose, research on sustainability standards has provided insightful knowledge about which standards are better suited to serve to create impact. While some writings emphasize the value of open-ended (e.g. principle-based) standards and their ability to adapt to different situations and contexts, others argue that closed standards (e.g. certification and reporting) are necessary to systematically assess and measure practices and in this way ensure compliance. And while both types of standards are frequently critiqued, scholars have begun to argue that openness and closure may supplement each other in practice (Gilbert et al., 2011; Reineke, Manning, \& Hagen, 2012). We acknowledge and support this understanding, but point out that sustainability standards often operate in social, organizational, and evaluative contexts that favor closure. For this reason, we argue, there is a growing need to develop practices that stimulate openness and contestation.

To that purpose we introduce the notion of "license to critique." License to critique is a managerial philosophy conceived to involve organizational members, draw on local knowledge and experience, advance critical thinking, and bring new ideas forth in the interest of the organization and the environment. Based on a research tradition that regards communication as constitutive of organization, we discuss and unfold 
communicative mechanisms that allow sustainability standards to remain relevant, vibrant, and adaptable to new challenges and situations. More specifically, we argue that sustainability standards are sensitizing devices that allow for critique and contestation in ways that ideally cultivate the following processes: 1) recognizing and confronting alternatives, 2) authorizing employee participation, and 3) talking out loud about sustainability in order to learn about it. We have also suggested three mechanisms to help adopting organizations integrate a license-to-critique approach in their daily routines: spaces for dissent, tolerance for aspirations, and standards as change agents. These principles and mechanisms are developed to counterbalance the bias towards closure in practices of standard implementation and use.

It may be argued, of course, that some newer standards are already embedding traits from the license-to-critique approach. The guidelines of standards from the B-Corporation, for example, focus on how to encourage managers to practice ongoing self-assessment and to perceive the B-standards as a "process of continual improvement" rather than "a quick fix." Also, Fairtrade International encourages the public to partake and comment in standard-setting and review processes. However, we know very little about how such invitations for dialogue and engagement actually stimulate challenging questions beyond the immediate comfort zone of managers, or whether, in fact, employees are raising challenging questions about the standards and with what effect.

Our conceptual contribution calls for further research, especially to understand the practical applicability of the license-to-critique approach. Overall, we emphasize the need for comparative empirical studies of how a license-to-critique philosophy is maintained in the different contexts of, respectively, principle-based, certification and reporting standards. Such studies may help us understand better the challenges associated with nurturing openness in different standard setting regimes.

Thus, first, we suggest investigating the role time or temporality plays in stimulating openness in standard adoption. The role of time has only been cursorily touched upon in this article. Yet, the license-to-critique perspective is essentially driven by the assumption that a critique of past or current practices is in fact engaging the future. Images of the future play an important and so far ignored role in the sustainability agenda (Garud \& Gehman, 2012). In previous work, we have argued that communication about sustainability is characterized by "aspirational talk" (Christensen et al., 2013). There is a need, however, to explore more systematically how organizations employ the future as a temporal resource in their sustainability standard work "to disrupt, transform, develop, discover, or restore a sense of collective self" (Ybema, 2010: 483). Ybema (2010), for example, has argued that the depiction of a "sparkling future identity" may be a reflection of "present day concerns" (497). And in their study of temporality, Costas and Grey (2014) show how "imaginary future selves" were used by professionals to dream and fantasize about contrasting identities. Inspired by these findings, and in line with the license-to-critique approach put forth in this article, we call for research that is able to conceptualize how notions of the future may be used to counter tendencies toward closure. While we assume that principle-based standards are more oriented towards the future and certification and reporting standards are more oriented towards the past, there is a lack of empirical 
evidence for such claims, and importantly, a lack of insights into the implications of employing the future to promote organizational openness for a license to critique.

Second, we call for studies that explore empirically and theoretically the boundary conditions of a license-to-critique approach: when, how, and under what conditions does such an approach serve to enhance standard work in organizations? While standard adoption has so far primarily been a task for larger organizations, more recently, a number of SMEs have become engaged in the issue. Since the literature on sustainability in SMEs has convincingly demonstrated that the context of SMEs differs considerably from MNCs, we may expect the same when it comes to the adoption of sustainability standards. SMEs have been said to be more flexible, innovative, and susceptible to change, but they have also been shown to be based in solid family-values motivated by an owner-manager (Spence, 2016). Such strongly held values may influence the possibility for ongoing critique and contestation. Two other contextual boundary conditions often mentioned in the sustainability literature are industry and geography. The financial sector, for example, is often described as relatively risk-averse and such propensity may produce an organizational culture where critique and challenge of standard adoption are regarded as counterproductive. By contrast creative industries such as the media, film and theater may find it natural to integrate a license-to-critique approach to their standards work. Finally, some countries and regions are known for hierarchical cultures where seniority or social position in the local community implies types of authority that cannot be challenged. In such cases, a sustainability standard may be perceived as a rule not to be questioned and a license to critique as an awkward structure that is encouraging deviant behavior. Thus, we encourage research that explores the geographical stretch of the license to critique in terms of its cultural potential as well as its cultural bias.

Third, we call for empirical studies of the social and discursive processes involved in developing a healthy tension between openness and closure. It is central to understand how leaders in practice create and retain a discursive balance that encourages ongoing contestation and testing of ideas and arguments without endorsing conflict or reducing efficiency. In particular, we welcome research on how leaders in celebrated standard adopting organizations discursively frame sustainability standards (whether these are principle-based, certification, or reporting standards). Recent research has suggested how successful leaders initiate strategic change by intentionally communicating "visionary ambiguity" in order to stimulate "revisions in fundamental assumptions, interpretations, knowledge, language, actions, and practices at individual and collective levels" (Gioia, Nag, \& Corley, 2012: 365). In a similar vein, we suggest empirically investigating how discursive ambiguity from leaders during sustainability standard adoption may accommodate multiple meanings and avoid conflict among different constituents in different positions.

Finally, it is our hope that scholarly work will theoretically and empirically explore the potential for openings in contexts where closure is dominating the implementation and use of sustainability standards. For example, we encourage research on the license-to-critique approach in cultural contexts where critique and contestation from employees is not normally appreciated or rewarded. By understanding better the 
potential and limitations of how critique may drive the sustainability agenda further, we hope to generate courage among adopters and motivate more organizations to subscribe substantially to sustainability standards. This, we believe, will serve the sustainability agenda as well as society in general.

The background for this article is a recognition of sustainability as an amorphous phenomenon that influences contemporary organizations "not as a clear or consistent agenda, but rather as a forum for sense making, diversity of opinion, and debate over the social norms and expectations attached to corporate activity" (Guthey \& Morsing, 2014: 555). Thus, when researchers state that sustainability is an arena in "constant flux" (Carroll, 1979) or in "a continuing state of emergence" (Lockett et al., 2006: 133), we read such observations as signs of appreciation for the ambiguity of the phenomenon and its communicative potential to stimulate debate and the search for alternatives and better practices.

\section{ACKNOWLEDGEMENTS}

We want to thank Professor Dennis Schoeneborn, three anonymous reviewers, and the guest editorial team for providing excellent guidance and suggestions in the development of the article. We also want to thank MSc Luisa Murphy for professional editorial help.

\section{NOTE}

1. The B Corp Handbook published by B Lab, p. 164. http://www.bcorporation.net/sites/default/files/ documents/The-B-Corp_Handbook_Sample.pdf.

\section{REFERENCES}

Ansari, S. M., Fiss, P. C., \& Zajac, E. J. 2010. Made to fit. How practices vary as they diffuse. Academy of Management Review, 35(1): 67-92.

Aravind, D., \& Christmann, P. 2011. Decoupling of standard implementation from certification: Does quality of ISO 14001 implementation affect facilities' environmental performance? Business Ethics Quarterly, 21(1): 73-102.

Argryis, C., \& Schon, D. 1996. Theory in practice. San Francisco: Jossey-Bass.

Argyris, C. 1976. Single-loop and double-loop models in research on decision making. Administrative Science Quarterly, 21(3): 363-375.

Ashcraft, K. L., Kuhn, T. R., \& Cooren, F. 2009. Constitutional amendments: Materiali-zing organizational communication. The Academy of Management Annals, 3(1): 1-64.

Austin, J. L. 1962. How to do things with words. Oxford: Oxford University Press.

. 1979. Philosophical papers. Oxford: Oxford University Press.

Becker, M. C., Lazaric, N., Nelson, R. R., \& Winter, S. G. 2005. Applying organizational routines in understanding organizational change. Industrial and Corporate Change, 14(5): 775-791.

Behnam, M., \& MacLean, T. L. 2011. Where is the accountability in international accountability standards?: A decoupling perspective. Business Ethics Quarterly, 21(1): 45-72.

Bitzer, V., Francken, M., \& Glasbergen, P. 2008. Intersectoral partnerships for a sustainable coffee chain: Really addressing sustainability or just picking (coffee) cherries?

Global Environmental Change, 18(2): 271-284. 
Boden, D. 1994. The business of talk. Organizations in action. Cambridge: Polity Press. Boiral, O. 2003. ISO 9000: Outside the iron cage. Organization Science, 14(6): 720-737.

Boje, D. M., Oswick, C., \& Ford, J. D. 2004. Language and organization: The doing of discourse. Academy of Management Review, 29(4): 571-577.

Brés, L., \& Gond, J. P. 2014. The visible hand of consultants in the construction of the markets for virtue: Translating issues, negotiating boundaries and enacting responsive regulations. Human Relations, 67(11): 1347-1382.

Bromley, P., \& Powell, W. W. 2012. From smoke and mirrors to walking the talk: Decoupling in the contemporary world. The Academy of Management Annals, 6(1): 1-48.

Brummans, B. H. J. M., Cooren, F., Robichaud, D., \& Taylor, J. R. 2014. Approaches to the communicative constitution of organizations. In L. Putnam \& D. K. Mumby (Eds.), The sage handbook of organizational communication ( $3^{\text {rd }}$ ed.): $173-194$. Thousand Oaks, CA: Sage Publications.

Brunsson, N., Rasche, A., \& Seidl, D. 2013 The dynamics of standardization: Three perspectives on standards in organization studies. Organization Studies, 33(5-6): 613-632.

Burt, R. S. 2005. Brokerage and closure: An introduction to social capital. Oxford: Oxford University Press.

Carroll, A. B. 1979. A three-dimensional conceptual model of corporate performance. Academy of Management Review, 4(4): 497-505.

Castello, I., Morsing, M., \& Schultz, F. 2013. Communicative dynamics and the polyphony of corporate social responsibility in the network society. Journal of Business Ethics, 118: 683-694.

Cheney, G., Christensen, L. C., Zorn Jr., T. E., \& Ganesh, S. 2011. Organizational communication in an age of globalization: Issues, reflections, practice (2nd ed.). Chicago: Waveland Press, Inc.

Chatterji, A., \& Levine, D. 2006. Breaking down the wall of codes: Evaluating non-financial performance measurement. California Management Review, 48(2): 29-51.

Christensen, L. T., Firat, F., \& Torp, S. 2008. The organization of integrated communications: Toward flexible integration. European Journal of Marketing, 42(3/4): 423-452.

Christensen, L. T., Morsing, M., \& Cheney, G. 2008. Corporate communications: Convention, complexity and critique. London, England: SAGE Publications.

Christensen, L. T., Morsing, M., \& Thyssen, O. 2013. CSR as aspirational talk. Organization, 20(3): 372-393.

Christmann, P., \& Taylor, G. 2006. Firm self-regulation through international certifiable standards: Determinants of symbolic versus substantive implementation. Journal of International Business Studies, 37(6): 863-878.

Cooren, F. 1999. The organizing property of communication. Amsterdam, The Netherlands: John Benjamins Publishing Company.

- 2004. Textual agency: How texts do things in organizational settings. Organization, 11(3): 373-393.

Cooren, F., Kuhn, T., Cornelissen, J. P., \& Clarke, T. 2011. Communication, organizing and organization: An overview and introduction to the special issue. Organization Studies, 32(9): 1149-1170.

Costas, J., \& Grey, C. 2014. The temporality of power and the power of temporality: Imaginary future selves in professional service firms. Organization Studies, 35(6): 909-937.

Cyert, R. M., \& March, J. G. 1963. A behavioral theory of the firm. Oxford: Blackwell. 
Dahlsrud, A. 2006. How corporate social responsibility is defined: An analysis of 37 definitions. Corporate Social Responsibility and Environmental Management, 15(1): 1-13.

Deetz, S. 1992. Democracy in an age of corporate colonization: Developments in communication and the politics of everyday life. Albany, NY: State University of New York Press.

2007. Corporate governance, corporate social responsibility, and communication. In S. May, G. Cheney, \& J. Roper (Eds.), The debate over corporate social responsibility: 267-278. Oxford, England: Oxford University Press.

Déjean, F., Gond, J. P., \& Leca, B. 2004. Measuring the unmeasured: An institutional entrepreneur strategy in an emerging industry. Human Relations, 57(6): 741-764.

Delmas, M. A., \& Burbano, V. C. 2011. The drivers of greenwashing. California Management Review, 54(1): 64-87.

Delmas, M. A., \& Montes-Sancho, M. J. 2011. An institutional perspective on the diffusion of international management system standards: The case of the environmental management standard ISO 14001. Business Ethics Quarterly, 21(1): 103-132.

Du, S., Bhattacharaya, C. B., \& Sen, S. 2010. Maximizing business returns to corporate social responsibility (CSR): The role of CSR communication. International Journal of Management Reviews, 12(1): 8-19.

Edelman, L. B. 1992. Legal ambiguity and symbolic structures: Organizational mediation of civil rights law. American Journal of Sociology, 97(06): 1531-1576.

Edelman, L. B., \& Talesh, S. 2011. To comply or not to comply - That isn't the question: How organizations construct meaning of compliance. In C. Parker \& V. L. Nielsen (Eds.), Explaining compliance: Business responses to regulation: 103-122. Cheltenham: Edward Elgar.

Fagin, R., Halpern, J. Y., Moses, Y., \& Vardi, M. Y. 1995. Reasoning about knowledge. Cambridge, MA: The MIT Press.

Fairhurst, G., \& Putnam, L. 2004. Organizations as discursive constructions. Communication Theory, 14(1): 5-26.

Ferraro, F., Etzion, D., \& Gehman, J. 2015. Tackling grand challenges pragmatically: Robust action revisited. Organization Studies, 36(3): 363-390.

Fransen, L. W., \& Kolk, A. 2007. Global rule-setting for business: A critical analysis of multi-stakeholder standards. Organization, 14(5): 667-684.

Garud, R., \& Gehman, J. 2012. Metatheoretical perspectives on sustainability journeys: Evolutionary, relational and durational. Research Policy, 41(6): 980-995.

Gilbert, D. U., \& Rasche, A. 2007. Discourse ethics and social accountability: The ethics of SA 8000. Business Ethics Quarterly, 17(2): 187-216.

Gilbert, D. U., Rasche, A., \& Waddock, S. 2011. Accountability in a global economy: The emergence of international accountability standards. Business Ethics Quarterly, 21(1): 23-44.

Gioia, D., Nag, R., \& Corley, K. G. 2012. Visionary ambiguity and strategic change: The virtue of vagueness in launching major organizational change. Journal of Management Inquiry, 21(4): 364-375.

González-Benito, J., \& González-Benito, O., 2005. An analysis of the relationship between environmental motivations and ISO14001 certification. British Journal of Management, 16(2): 133-148.

Grant, D., Keenoy, T., \& Oswick, C. (Eds.). 1998. Discourse + organization. London: Sage Publications. 
Guthey, E., \& Morsing, M. 2014. CSR and the mediated emergence of strategic ambiguity. Journal of Business Ethics, 120(4): 555-569

Haack, P., Schoeneborn, D., \& Wickert, C. 2012. Talking the talk, moral entrapment, creeping commitment? Exploring narrative dynamics in corporate responsibility standardization. Organization Studies, 33(5-6): 815-845.

Haack, P., \& Schoeneborn, D. 2014. Is decoupling becoming decoupled from institutional theory? A commentary on Wijen. Academy of Management Review, 40(2): 307-313.

Hale, A., \& Opondo, M. 2005. Humanising the cut flower chain: Confronting the realities of flower production for workers in Kenya. Antipode, 37(2): 301-323.

Kärreman, D., \& Alvesson, M. 2003. Understanding ethical closure in organizational settings: The case of media organizations. Working Paper Series, Institute of Economic Research, Lund University.

King, A. A., Lenox, M. J., \& Terlaak, A. 2005. The strategic use of decentralized institutions: Exploring certification with the IOS 14001 management standard. Academy of Management Journal, 48(6): 1091-1106.

Kjærgaard, A., Morsing, M., \& Ravasi, D. 2011. Mediating identity: A study of media influence on organizational identity construction in a celebrity firm. Journal of Management Studies, 48(3): 514-543.

Kjærgaard, A., \& Morsing, M. 2010. Strategic auto-communication in identity-image interplay: The dynamics of mediatizing organizational identity. In L. Chouliaraki \& M. Morsing (Eds.) Media, organizations, and identity: 93-111. London: Macmillan Palgrave.

Knudsen, H. 2004. Licens til kritik - og andre måder at bruge værdier på i organisationer. In D. Pedersen (Ed.), Offentlig ledelse i managementstaten:159-175. København: Samfundslitteratur.

Kwon, D-M., Seo, M-S., \& Seo, Y-C. 2002. A study of compliance with environmental regulations of ISO 14001 certified companies in Korea. Journal of Environmental Management, 65(4): 347-353.

Livesey, S. M. 2002. The discourse of the middle ground. Citizen Shell commits to sustainable development. Management Communication Quarterly, 15(3): 313-349.

Livesey, S. M., Hartman, C. L., Stafford, E. R., \& Shearer, M. 2009. Performing sustainable development through eco-collaboration. The Riceland Habitat Partnership. Journal of Business Communication, 46(4): 423-454.

Lockett, A., Moon, J., \& Visser, W. 2006. Corporate social responsibility in management research: Focus, nature, salience and sources of influence. Journal of Management Studies, 43(1): 115-136.

Luhmann, N. 1993. Risk: a Sociological Theory. New York: A. de Gruyter. . 1995. Social systems. J. Bednarz, Jr. \& D. Baeker (Trans.). Stanford, CA: Stanford University Press. (Original work published 1984).

. 2000. Organisation und Entscheidung. Opladen: Westdeutscher Verlag.

Maon, F., Lindgreen, A., \& Swaen, V. 2009. Designing and implementing corporate social responsibility: An integrative framework grounded in theory and practice. Journal of Business Ethics, 87(1): 71-89.

March, J. G., \& Simon, H.A. 1958. Organizations. Oxford: Blackwell.

McWilliams, A., Siegel, D. S., \& Wright, P. M. 2006. Corporate social responsibility:

Strategic implications. Journal of Management Studies, 43(1): 1-18.

Miller, P., \& Rose, N. 1990. Governing economic life. New York: Francis Taylor. 
Morhardt, J. E., Baird, S., \& Freeman, K. 2002. Scoring corporate environmental and sustainability reports using GRI 2000, ISO 14031 and other criteria. Corporate Social Responsibility and Environmental Management, 9(4): 215-233.

Okoye, A. 2009. Theorizing corporate social responsibility as an essentially contested concept: Is a definition necessary? Journal of Business Ethics, 89(4): 613-627.

Power, M. 1997. The audit society: Rituals of verification. Oxford: Oxford University Press.

Rasche, A., \& Esser, D. E. 2007. Managing for compliance and integrity in practice. In S. Clegg, M. Kornberger, \& C. Rhodes (Eds.), Business ethics as practice: 107-127. Northampton: Edward Elgar.

Rasche, A. 2009. Toward a model to compare and analyze accountability standards. Corporate Social Responsibility and Environmental Management, 16(4): 192-205.

. 2010. The limits of responsibility standards. Business Ethics: A European Review, 19(3): 280-291.

. 2012. Global policies and local practice: Loose and tight couplings in multistakeholder initiatives. Business Ethics Quarterly, 22(4): 679-708.

Reinecke, J., Manning, S., \& Von Hagen, O. 2012. The emergence of a standards market: Multiplicity of sustainability standards in the global coffee industry. Organization Studies, 33(5/6): 789-812.

Rose, N. 1989. Governing the soul: The shaping of the private self. London: Routledge.

Schoeneborn, D. 2011. Organization as communication: A Luhmannian perspective. Management Communication Quarterly, 24(4): 663-689.

Schuler, D. A., \& Christmann, P. 2011. The effectiveness of market-based social governance schemes: The case of fair trade coffee. Business Ethics Quarterly, 21(1): 133-156.

Searle, J. R. 1969. Speech acts: An essay in the philosophy of language. Cambridge: Cambridge University Press.

Seidl, D. 2005. General strategy concepts and the ecology of strategy discourses: A systemic-discursive perspective. Organization Studies, 28(2): 197-218.

Sethi, S. P., \& Schepers, D. H. 2014. United Nations Global Compact: The promiseperformance gap. Journal of Business Ethics, 122(2): 193-208.

Spence, L. J. 2016. Small business social responsibility: Expanding core CSR theory. Business and Society, 55(1): 23-55.

Steelman, T. A., \& Rivera, J. 2006. Voluntary environmental programs in the United States. Whose interests are served? Organization \& Environment, 19(4): 505-526.

Strathern, M. 2000. Audit cultures: Anthropological studies in accountaiblity, ethics and the academy. New York: Routledge.

Taylor, J. R., \& Cooren, F. 1997. What makes communication 'organizational'?: How the many voices of a collectivity become the one voice of an organization. Journal of Pragmatics, 27(4): 409-438.

Taylor, J. R., \& Van Every, E. J. 2000. The emergent organization. Communication as its site and surface. Mahwah, NJ: Lawrence Erlbaum Associates.

Terlaak, A. 2007. Order without law? The role of certified management standards in shaping socially desired firm behaviors. Academy of Management Review, 32(3): 968-985.

Thackaberry, J. A. 2004. Discursive opening and closing in organisational self-study. Culture as trap and tool in wildland firefighting safety. Management Communication Quarterly, 17(3): 319-359.

Thyssen, O. 2009. Business ethics and organizational values. London: Palgrave Macmillan. 
Timmermans, S., \& Epstein, S. 2010. A world of standards but not a standard world: Toward a sociology of standards and standardization. Annual Review of Sociology, 36: 69-89.

Weaver, G. R., Trevino, L. K., \& Cochran, P. L. 1999. Integrated and decoupled corporate social performance: Management commitments, external pressures, and corporate ethics practices. Academy of Management Journal, 42(5), 539-552.

Weick, K. E. 1979. The social psychology of organizing (2nd ed). New York: Random House.

1995. Sensemaking in organizations. Thousand Oaks, CA: Sage.

Weick, K. E., Sutcliffe, K. M., \& Obstfeld, D. 2005. Organizing and the process of sensemaking. Organization Science, 16(4): 409-421.

Wickert, C., \& de Bakker, F. 2015. Selling social issues: Uncovering managerial struggles during corporate social responsibility implementation. Paper presented at IABS Conference, Guanacaste, Costa Rica.

Wijen, F. 2014. Means versus ends in opaque institutional fields: Trading off compliance and achievement in sustainability standard adoption. Academy of Management Review, 39(3): 302-323.

Woo, C. 2010. Implementing the United Nations Global Compact. In A. Rasche \& G. Kell (Eds.), The United Nations Global Compact: Achievements: 115-143. New York: Cambridge University Press.

Ybema, S. 2010. Talk of change: Temporal contrasts and collective identities. Organization Studies, 31(4): 481-503.

Zeitz, G., Mittal, V., \& McAuley, B. 1999. Distinguishing adoption and entrenchment of management practices: A framework for analysis. Organization Studies, 20(5): 741-776. 